Contents list avaliable at Directory of Open Access Journals (DOAJ)
Aulad : Journal on Early Childhood
Vol 3 No 222020, Pages 95-102
ISSN : 2655-4798 (Printed); 2655-433X (Online)
Journal Homepage: https://aulad.org/index.php/aulad

\title{
Hubungan Self Esteem dengan Penyesuaian Diri pada Anak Usia 4-5 Tahun
}

\author{
Salsabila Firdausia ${ }^{1}$, Ria Novianti ${ }^{2}$, Rita Kurnia ${ }^{3}$ \\ Pendidikan Guru Pendidikan Anak Usia Dini, Universitas Riau \\ DOI: 10.31004/aulad.v3i2.68
}

\begin{abstract}
Article Info Abstract
Kata Kunci:

self esteem,

penyesuaian diri,

anak usia dini

Penelitian ini bertujuan untuk mengetahui hubungan antara variabel Self Esteem $(\mathrm{X})$ dan variabel penyesuaian diri (Y). Penelitian ini adalah penelitian kuantitatif dengan jenis penelitian korelasi yang dilakukan pada anak usia 4-5 tahun di TK Negeri Pembina 2 Bengkalis pada bulan Februari hingga Juli tahun 2020. Teknik pengambilan sampel yang digunakan adalah random sampling dengan jumlah sampel sebanyak 83 orang anak. Hasil penelitian menunjukkan Penyesuaian diri anak usia 45 tahun di TK Negeri Pembina 2 Bengkalis Kecamatan Bengkalis Kabupaten Bengkalis secara umum tergolong dalam kategori masih berkembang. Artinya, kemampuan anak untuk menyesuaikan diri, mengubah diri sesuai dengan keadaan lingkungan, dan juga mengubah lingkungan sesuai dengan keadaan diri dalam kategori masih perlu dikembangkan. Berdasarkan keseluruhan indikator, Self Esteem anak juga masih berkembang Artinya, kemampuan anak menunjukkan harga diri, menghadapi tugas dan orang lain dengan penuh pengharapan akan sukses diterima, dan adanya kepercayaan dan penghargaan terhadap dirinya sendiri dalam kategori masih perlu dikembangkan.
\end{abstract}

Keyword: self esteem, selfadjustment, early childhood

\section{Abstrak}

This study aims to determine the relationship between the Self Esteem variable $(X)$ and the adjustment variable $(Y)$. This research is a quantitative study with the type of correlation research conducted on children aged 4 to 5 years at TK Negeri Pembina 2 Bengkalis from February to July 2020. The sampling technique used was random sampling with a total sample of 83 children. The results showed that the adjustment of children aged 4 to 5 years in at TK Negeri Pembina 2 Bengkalis, Bengkalis District, Bengkalis Regency was generally classified as still developing. It means that the ability of children to adjust, change themselves in accordance with environmental conditions, and also to change the environment in accordance with the state of the himself in the category still needs to be developed. Based on all indicators, the child's Self Esteem is still developing. It means that the child's ability to show self-esteem, dealing with tasks and other peole with full expectation of success will be accepted, and the existence of trust and respect for himself in the category still needs to be developed.

\footnotetext{
${ }^{1}$ Corresponding author at: Pendidikan Guru Pendidikan Anak Usia Dini, Universitas Riau.

Email: salsabilafirdausia.firdausia@gmail.com

2 Pendidikan Guru Pendidikan Anak Usia Dini, Universitas Riau

${ }^{3}$ Pendidikan Guru Pendidikan Anak Usia Dini, Universitas Riau
} 


\section{PENDAHULUAN}

Masa usia dini merupakan periode emas (Golden Age) bagi perkembangan anak untuk memperoleh proses pendidikan. Periode ini adalah tahun-tahun berharga bagi seorang anak untuk mengenali berbagai macam fakta di lingkungan sebagai stimulasi terhadap perkembangan kepribadian, pisikomotor, kognitif, maupun sosialnya. Untuk itu pendidikan anak usia dini merupakan pemberian rangsangan-rangsangan (stimulasi) dari lingkungan terdekat sangat di perlukan untuk mengoptimalkan keperluan anak.

Undang-Undang Nomor 20 Tahun 2003 tentang Sistem pendidikan Nasional Pasal 1 angka 14 menyatakan bahwa Pendidikan Anak Usia Dini (PAUD) adalah suatu upaya pembinaan yang ditujukan kepada anak sejak lahir sampai dengan usia enam tahun yang dilakukan melalui pemberian rangsangan pendidikan untuk membantu pertumbuhan dan perkembangan jasmani dan rohani agar anak memiliki kesiapan dalam memasuki pendidikan lebih lanjut (Sisdiknas, 2003). Terdapat 6 aspek perkembangan yang harus dikembangkan oleh guru PAUD yakni; aspek perkembangan nilai agama dan moral, koginitf, sosial emosional, Bahasa fisik motorik, dan seni (Fauziddin \& Mufarizuddin, 2018)

Pendidikan Anak Usia Dini yang selanjutnya disingkat PAUD adalah suatu upaya pembinaan yang ditujukan kepada anak sejak lahir sampai dengan usia 6 (enam) tahun yang dilakukan melalui pemberian rangsangan pendidikan untuk membantu pertumbuhan dan perkembangan jasmani dan rohani agar anak memiliki kesiapan dalam memasuki pendidikan lebih lanjut (Kemdikbud 2015).

Berdasarkan observasi peneliti di TK Negeri Pembina 2 Bengkalis Kecamatan Bengkalis Kabupaten Bengkalis penyesuaian diri anak dapat terlihat seperti: 1) adanya beberapa anak yang belum bisa menyesuaikan diri dengan lingkungan sekolah, anak yang belum bisa berinteraksi dengan teman dan guru. Hal ini disebabkan ketidakmampuan anak dalam menghadapi hambatan-hambatan dan mengatasi kegagalan-kegagalan yang terjadi. Sehingga mengakibatkan terjadi ketegangan, 2) ada beberapa anak yang kurang percaya diri, seperti malu tidak berani tampil ke depan, tidak berani mengungkapkan gagasan, dan tidak berani mengatakan apa yang dirasakannya, 3) ada beberapa anak merasa dirinya lebih rendah dibandingkan dengan teman-temannya dan merasa dirinya tidak memiliki kemampuan. Hal ini terjadi karena anak sudah memiliki kecemasan dalam ketidakpercayaan terhadap dirinya sendiri.

Anak-anak yang tidak mampu menyesuaikan diri di sekolah akan menghadapi masalah yang bertumpuktumpuk dan menetap karena faktor sosial-psikologis, misalnya penyimpangan reputasional. Hal ini akan memperburuk keadaan saat kesulitan muncul dan menghambat perkembangan selanjutnya. Anak yang mempunyai daya suai kurang akan cenderung menarik diri dari lingkungannya karena merasa tidak mampu mengadakan hubungan yang dekat dengan orang lain, merasa rendah diri, ragu, dan kurang percaya diri.

Tujuan penelitian ini adalah: (1) Untuk mengetahui bagaimana penyesuaian diri pada anak usia 4-5 tahun di TK Negeri Pembina 2 Bengkalis Kecamatan Bengkalis Kabupaten Bengkalis, (2) Untuk mengetahui Bagaimana Self Esteem pada anak usia 4-5 tahun di TK Negeri Pembina 2 Bengkalis Kecamatan Bengkalis Kabupaten Bengkalis, (3) Untuk mengetahui Hubungan Self Esteem Dengan Penyesuaian Diri Anak Usia 4-5 Tahun Di TK Negeri Pembina 2 Bengkalis Kecamatan Bengkalis Kabupaten Bengkalis.

\section{KAJIAN TEORI}

Self Esteem atau harga diri adalah penilaian atau perasaan seseorang tentang diri nya. Harga diri atau penghargaan diri (Self esteem) adalah pandangan keseluruhan dari individu tentang dirinya sendiri. Penghargaan diri juga kadang dinamakan martabat diri (self worth) atau gambaran diri (self image) (Santrock, 2012). Individu yang memilki harga diri yang tinggi berarti memandang dirinya secara positif. Individu dengan harga diri yang tinggi sadar akan kelebihan-kelebihan yang dimilikinya dan memandang kelebihan-kelebihan tersebut lebih penting dari pada kelemahannya. Sebaliknya individu dengan harga diri rendah cenderung memandang dirinya secara negatif dan terfokus pada kelemahan dirinya (Maria dan Novianti, 2017)

Penyesuaian diri merupakan sikap di mana seseorang berusaha untuk diterima oleh suatu kelompok. Pada anak usia dini kemampuan dalam menyesuaikan diri ditunjukkan dengan mengenali ingkungan sekitarnya. Kemampuan sosial tersebut akan muncul pada usia 4-6 tahun karena pada usia tersebut anak sudah mulai mengenal sekolah dan lingkungan luar. Penyesuaian diri pada anak dapat ditinjau dengan rasa nyaman anak pada suatu kelompok. Sebaliknya anak yang tidak dapat menyesuaikan diri dengan lingkungannya ditinjau dari sikap anak yang menunjukkan frustasi, pemalu, dan menangis (Auni, 2017).

\section{METODE PENELITIAN}

Penelitian ini adalah penelitian kuantitatif dengan jenis penelitian korelasi. Penelitian ini akan mencari tahu hubungan antara variabel satu dengan variabel lain yang digambarkan dalam bagan berikut: 


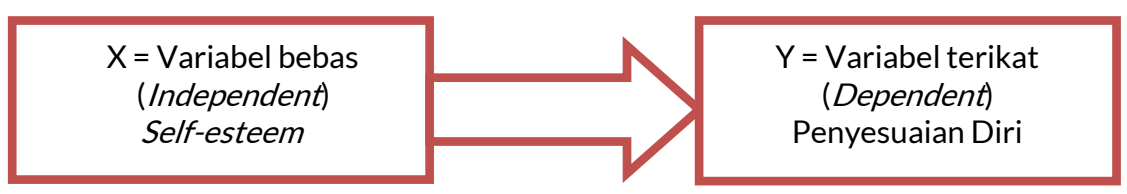

\section{Gambar 1 Variabel penelitian}

Populasi dalam penelitian ini adalah anak TK Negeri Pembina 2 Bengkalis Kecamatan Bengkalis Kabupaten Bengkalis yang berjumlah 83 anak dengan rincian sebagai berikut; kelas A.1 sebanyak 16 orang, kelas A.2 sebanyak 16 orang, B.1 sebanyak 18 orang, kelas B.2 sebanyak 16 orang, dan kelas B.3 sebanyak 17.

Analisis statistik deskriptif yang dipakai dalam penelitian ini yaitu dengan mendeskripsikan data dengan distribusi frekuensi, histrogram, pengukuran nilai sentral mean (rerata), modus, median, dan standar deviasi (simpangan baku). Adapun proses analisis data dilaksanakan dengan menggunakan SPSS Ver.17 for windows. Adapun langkah-langkah analisis data adalah dengan melakukan analisis koefisien korelasi product moment menggunakan koefisien korelasi $r$ pearson.

Selanjutnya untuk mengetahui koefisien determinasi atau besarnya hubungan tersebut digunakan rumus sebagai berikut:

Keterangan:
$\mathrm{KD} \quad=$ Koefisien Determinasi
$\mathrm{r} 2 \quad=$ Koefisien Korelasi Product Moment

Uji hipotesis atau uji persyaratan dengan menggunakan program komputer SPSS Ver.17 for windows. Sebelum pengujian hipotesis terlebih dahulu dilakukan ujian homogenitas yang bertujuan untuk mengetahui apakah data penelitian yang diperoleh homogen atau tidak. Uji normalitas yang bertujuan untuk memeriksa apakah data populasi berdistribusi normal/tidak normal dengan menggunakan uji Kolmogorov-Smirnov. Sedangkan uji linieritas dimaksud untuk melihat bagaimana bentuk hubungan antara satu variabel bebas dengan variabel terikat.

Tabel Interprestasi Koefisien Korelasi Nilai r

\begin{tabular}{cc}
\hline Interval Koefisien & Tingkat Hubungan \\
\hline $0,00-0,199$ & Sangat rendah \\
$0,20-0,399$ & Rendah \\
$0,40-0,599$ & Sedang \\
$0,60-0,799$ & Kuat \\
$0,80-1,000$ & Sangat kuat \\
\hline
\end{tabular}

(Sugiono, 2015)

Sebelum melakukan Uji hipotesis maka terlebih dahulu dilakukan Uji hipotesis atau uji prasyarat dengan menggunakan program komputer SPSS Ver.17 for windows, yang berupa uji normalitas yang bertujuan untuk memeriksa apakah data populasi berdistribusi normal atau tidak normal dengan menggunakan uji kolmogrovsmirnov, uji linieritas dimaksudkan untuk melihat bagaimana bentuk hubungan antara variabel bebas dengan variabel terikat dan uji homogenitas yang bertujuan untuk mengetahui data penelitian homogen atau tidak.

\section{HASIL DAN PEMBAHASAN}

Gambaran mengenai penyesuaian diai anak Usia 4-5 tahun di TK Negeri Pembina 2 Bengkalis Kecamatan Bengkalis Kabupaten Bengkalis dapat dilihat pada tabel berikut:

Tabel 1 Indikator Variabel Penyesuaian Diri Anak Usia 4-5 Tahun.

\begin{tabular}{clccc}
\hline No & Aspek Yang Diobservasi & $\begin{array}{c}\text { Skor } \\
\text { Empirik }\end{array}$ & $\begin{array}{c}\text { Rata- } \\
\text { rata }\end{array}$ & Kategori \\
\hline 1. & Anak sudah memiliki prilaku penerimaan individu terhadap diri sendiri & 227 & 2,73 & MB \\
2. & Anak sudah mampu mengontrol diri sendiri & 230 & 2,77 & $\mathrm{MB}$ \\
3. & Anak sudah mampu mengarahkan diri sendiri & 237 & 2,86 & $\mathrm{MB}$ \\
4. & Anak sudah mampu memiliki hubungan interpersonal yang baik & 233 & 2,81 & $\mathrm{MB}$ \\
5. & Anak sudah memiliki simpati pada orang lain & 217 & 2,61 & $\mathrm{MB}$ \\
6. & Anak sudah mampu menghargai orang lain & 228 & 2,75 & $\mathrm{MB}$ \\
7. & Anak sudah bisa ikut berpartisipasi pada kelompok & 245 & 2,95 & $\mathrm{MB}$ \\
8. & Anak sudah mampu mengambil keputusan sendiri & 249 & 3,00 & $\mathrm{BSH}$ \\
9 & Anak sudah mampu bersosialisasi dengan baik pada teman dan guru & 246 & 2,96 & $\mathrm{MB}$ \\
& Rata-rata & & 2,22 & $\mathrm{MB}$ \\
\hline
\end{tabular}


Tabel di atas menunjukkan jumlah skor masing-masing indikator dari penyesuaian diri, dimana secara deskriptif dapat ditunjukkan bahwa nilai (skor) dari indikator anak sudah memiliki prilaku penerimaan individu terhadap diri sendiri memperoleh skor 227 dengan rata-rata 2,73 kategori masih berkembang (MB). Indikator anak sudah mampu mengontrol diri sendiri memperoleh skor 230 dengan rata-rata 2,77 kategori masih berkembang (MB). Indikator anak sudah mampu mengarahkan diri sendiri memperoleh skor 237 dengan rata-rata 2,86 kategori masih berkembang (MB). Indikator anak sudah mampu memiliki hubungan interpersonal yang baik memperoleh skor 233 dengan rata-rata 2,81 kategori masih berkembang (MB). Indikator anak sudah memiliki simpati pada orang lain memperoleh skor 217 dengan rata-rata 2,61 kategori masih berkembang (MB). Indikator anak sudah mampu menghargai orang lain memperoleh skor 228 dengan rata-rata 2,75 kategori masih berkembang (MB). Indikator anak sudah bisa ikut berpartisipasi pada kelompok memperoleh skor 245 dengan rata-rata 2,95 kategori masih berkembang (MB). Indikator anak sudah mampu mengambil keputusan sendiri memperoleh skor 249 dengan ratarata 3,00 kategori berkembang sesuai harapan (BSH). Indikator anak sudah mampu bersosialisasi dengan baik pada teman dan guru memperoleh skor 246 dengan rata-rata 2,96 kategori masih berkembang (MB). Rata-rata indikator variabel penyesuaian diri anak usia 4-5 tahun di TKN 2 Pembina Bengkalis Kecamatan Bengkalis Kabupaten Bengkalis adalah 2,22 dengan kategori masih berkembang (MB). berikut ini::

Untuk memberikan gambaran yang jelas, empat kategori penyesuaian diri anak disajikan dalam tabel

Tabel 2 Kategori Variabel Penyesuaian Diri Anak Usia 4-5 Tahun

\begin{tabular}{lll}
\hline No & Kategori & Skor \\
\hline 1 & Berkembang sangat baik & $33<\mathrm{X}$ \\
2 & Berkembang sesuai harapan & $28<\mathrm{X} \leq 33$ \\
3 & Masih Berkembang & $23<\mathrm{X} \leq 28$ \\
4 & Belum Berkembang & $\mathrm{X} \leq 23$ \\
\hline
\end{tabular}

Melihat rata-rata empirik yang dihasilkan oleh keseluruhan subjek yaitu sebesar 25,45 maka dapat diketahui bahwa penyesuaian diri anak berada dalam kategori masih berkembang.

Gambaran mengenai Self Esteem anak TK Negeri Pembina 2 Bengkalis Kecamatan Bengkalis Kabupaten Bengkalis dapat dilihat pada tabel berikut ini:

Tabel 3 Skor Indikator Self Esteem Anak Usia 4-5 Tahun

\begin{tabular}{|c|c|c|c|c|}
\hline No & Aspek Yang Diobservasi & $\begin{array}{c}\text { Skor } \\
\text { Empirik }\end{array}$ & $\begin{array}{l}\text { Rata- } \\
\text { rata }\end{array}$ & Kategori \\
\hline 1. & $\begin{array}{l}\text { Anak mau menerima kritik dan saran dari teman atau guru } \\
\text { terhadap dirinya. }\end{array}$ & 251 & 3,02 & $\mathrm{BSH}$ \\
\hline 2. & $\begin{array}{l}\text { Anak suka membuat kelucuan, bersikap ramah dan suka } \\
\text { bergaul sehingga teman lain suka berteman dengannya }\end{array}$ & 229 & 2,76 & MB \\
\hline 3. & Anak mampu menyelesaikan tugasnya sendiri & 253 & 3,05 & $\mathrm{BSH}$ \\
\hline 4. & $\begin{array}{l}\text { Anak sudah mampu memiliki hubungan interpersonal yang } \\
\text { baik }\end{array}$ & 247 & 2,98 & MB \\
\hline 5. & Anak mampu mentaati aturan yang ada di sekolah & 243 & 293 & MB \\
\hline 6. & $\begin{array}{l}\text { Anak mampu menahan emosiya didepan teman atau guru } \\
\text { ketika ada masalah }\end{array}$ & 235 & 2,83 & MB \\
\hline 7. & $\begin{array}{l}\text { Anak mampu menunjukkan bakat yang ia minati } \\
\text { Rata-rata }\end{array}$ & 231 & $\begin{array}{l}2,78 \\
2,91\end{array}$ & $\begin{array}{l}\text { MB } \\
\text { MB }\end{array}$ \\
\hline
\end{tabular}

Tabel di atas menunjukkan jumlah skor masing-masing indikator dari Self Esteem, dimana secara deskriptif dapat ditunjukkan bahwa Indikator anak mau menerima kritik dan saran dari teman atau guru terhadap dirinya memperoleh 251 dengan rata-rata 3,02 kategori berkembang sesuai harapan (BSH). Indikator anak suka membuat kelucuan, bersikap ramah dan suka bergaul sehingga teman lain suka berteman dengannya memperoleh nilai 229 dengan rata-rata 2,76 kategori masih berkembang (MB). Indikator anak mampu menyelesaikan tugasnya sendiri memperoleh nilai 253 dengan rata-rata 3,05 kategori berkembang sesuai harapan(BSH). Indikator anak sudah mampu memiliki hubungan interpersonal yang baik memperoleh nilai 247 dengan rata-rata 2,98 kategori masih berkembang (MB). Indikator anak mampu mentaati aturan yang ada di sekolah memperoleh nilai 243 dengan ratarata 2,93 kategori masih berkembang (MB). Indikator anak mampu menahan emosiya didepan teman atau guru ketika ada masalah memperoleh nilai 235 dengan rata-rata 2,83 kategori masih berkembang (MB). Indikator anak mampu menunjukkan bakat yang ia minati memperoleh nilai 231 dengan rata-rata 2,78 kategori masih berkembang (MB). Rata-rata indikator Self Esteem adalah 2,91 dengan kategori masih berkembang (MB).

Sebaran skor secara keseluruhan dibuat dalam empat kategori kelompok Self Esteemanak disajikan dalam tabel berikut: 
Tabel 4 Kategori Variabel Self Esteem Anak Usia 4-5 Tahun

\begin{tabular}{lll}
\hline No & Kategori & Skor \\
\hline 1 & Berkembang sangat baik & $26<\mathrm{X}$ \\
2 & Berkembang sesuai harapan & $22<\mathrm{X} \leq 26$ \\
3 & Masih berkembang & $18<\mathrm{X} \leq 22$ \\
4 & Belum berkembang & $\mathrm{X} \leq 18$ \\
\hline
\end{tabular}

Melihat rata-rata empirik yang dihasilkan oleh keseluruhan subjek yaitu sebesar 20,35 maka dapat diketahui bahwa Self Esteemanak berada dalam kategori masih berkembang.

\section{Uji Asumsi}

Uji normalitas menggunakan One Sampel Kolmogorov-Smirnov dengan ketentuan yang telah digunakan adalah jika Sig < 0,05 maka data tidak berdistribusi normal, sebaliknya jika Sig > 0,05 maka data berdistribusi normal (Sugiyono, 2012). Untuk hasil pengujian normalitas dapat dilihat pada tabel berikut ini:

One-Sample Kolmogorov-Smirnov Test

\begin{tabular}{llrr}
\hline & & Self Esteem & Penyesuaian Diri \\
\hline $\mathrm{N}$ & & 83 & 83 \\
& Mean & 20.34940 & 25.44578 \\
& Std. Deviation & 3.849085 & 5.229497 \\
& Absolute & .114 & .112 \\
& Positive & .114 & .103 \\
& Negative & -.092 & -.112 \\
Kolmogorov-Smirnov Z & & 1.043 & 1.019 \\
Asymp. Sig. (2-tailed) & & .227 & .250 \\
\hline
\end{tabular}

Dari hasil uji normalitas kolmogorov-smirnov di atas didapat bahwa data kedua variabel tersebut dalam distribusi datanya telah memenuhi distribusi normal. Syarat signifikan $>0,05$. Untuk variabel Self Esteem mempunyai signifikan 0,227 >0,05 dan untuk variabel penyesuaian diri memiliki signifikan 0,250>0,05.

Dapat disimpulkan bahwa untuk variabel terikat yaitu Penyesuaian Diri $(\mathrm{Y})$ dan variabel bebas Self Esteem (X) berasal dari populasi pada taraf signifikan 0,05 , maka secara statistik telah berdistribusi secara normal dan layak digunakan sebagai data penelitian.

Uji Linieritas dilakukan untuk mengetahui bentuk hubungan antara variabel bebas yaitu Self Esteem $(\mathrm{X})$ dan variabel terikat yaitu Penyesuaian Diri (Y). Pengujian Linieritas menggunakan SPSS Ver.17. Pengujian ini dilakukan untuk menentukan analisis regresi antara variabel seperti yang terdapat pada tabel berikut ini:

Tabel 6 Hasil Uji Linieritas

\begin{tabular}{llrrrrr}
\hline & & Sum of & & Mean & & \\
& & Squares & \multicolumn{1}{c}{ df } & \multicolumn{1}{c}{ Square } & \multicolumn{1}{c}{$\mathrm{F}$} & \multicolumn{1}{c}{ Sig. } \\
\hline & (Combined) & 446.987 & 19 & 23.526 & 1.930 & .027 \\
& Linearity & 293.350 & 1 & 293.350 & 24.068 & .000 \\
& Deviation from & 153.637 & 18 & 8.535 & .700 & .798 \\
& Linearity & & & & & \\
Within Groups & & 767.881 & 63 & 12.189 & & \\
Total & & 1214.867 & 82 & & & \\
\hline
\end{tabular}

Dua variabel dikatakan mempunyai hubungan linier apabila $P<0,05$. Berdasarkan tabel di atas menghasilkan nilai $F=0,7$ dengan signifikan variabel bernilai $5 \%$ atau 0,05 . Maka dapat disimpulkan bahwa garis antara Self Esteem dengan Penyesuaian Diri anak di TK Negeri Pembina 2 Bengkalis Kecamatan Bengkalis Kabupaten Bengkalis mempunyai hubungan linier. Karena hasil analisis menunjukkan bahwa Sig 0,000 $<0,05$ sehingga dapat dikatakan bahwa hubungan kedua variabel tersebut linier.

Uji homogenitas dilakukan untuk mengetahui apakah data penelitian yang diperoleh homogen atau tidak. Pada suatu penelitian data disebut homogen apabila $\mathrm{P}>0,05$. Uji homogenitas dalam penelitian ini dapat dilihat pada tabel berikut ini:

Tabel 7 Hasil Uji Homogenitas

\begin{tabular}{cccc}
\hline \multicolumn{4}{c}{ Penyesuaian Diri } \\
\hline Levene Statistic & df1 & df2 & Sig. \\
\hline 1.418 & 12 & 69 & .179 \\
\hline \multicolumn{4}{c}{ Sumber: Data Olahan 2020 } \\
& Page $\mathbf{9 9}$ of $\mathbf{1 0 2}$ &
\end{tabular}


Berdasarkan hasil uji homogenitas di atas, diperoleh nilai signifikansi (sig) sebesar 0,179. Karena nilai sig. $0,179>0,05$, maka dapat disimpulkan bahwa varians data variabel Self Esteem dan variabel penyesuaian diri adalah sama atau homogen.

Uji hipotesis bertujuan untuk mengetahui data sesuai dengan hipotesis dan tujuan penelitian yaitu untuk mengetahui ada tidaknya hubungan Self Esteem dengan Penyesuian Diri anak usia 4-5 tahun di TK Negeri Pembina 2 Bengkalis Kecamatan Bengkalis Kabupaten Bengkalis.

Hasil uji hipotesis menunjukkan bahwa data yang terkumpul memenuhi syarat untuk dianalisis. Selanjunya dilakukan uji Corelate Bivariate untuk mengetahui jenis hubungan antara dua variabel dalam penelitian ini. Berdasarkan perhitungan Corelate Bivariate Analysis antara Self Esteem $(\mathrm{X})$ dengan Penyesuaian Diri $(\mathrm{Y})$ dengan menggunakan SPSS Ver.17 maka dapat diperoleh hasil sebagai berikut.

Tabel 8 Hasil Uji Hipotesis

\begin{tabular}{lcc}
\hline & Correlations & \\
\hline & Self Esteem & Penyesuaian Diri \\
\hline Pearson Correlation & 1 & $.491^{* *}$ \\
Sig. (2-tailed) & & .000 \\
N & 83 & 83 \\
Pearson Correlation & $.491^{* *}$ & 1 \\
Sig. (2-tailed) & .000 & \\
N & 83 & 83
\end{tabular}

Pada hasil uji korelasi diperoleh angka probabilitas sebesar 0,000. Dimana 0,000 lebih kecil dari 0,05 (0,000 $<0,05)$. Maka Ho ditolak artinya terdapat hubungan yang signifikan antara Self Esteem dengan Penyesuaian Diri. Koefisien korelasi yang dihasilkan adalah sebesar 0,491 yang terletak pada rentang 0,40-0,599 dengan kategori sedang artinya hubungan antara Self Esteem dengan Penyesuaian Diri anak masuk dalam kategori sedang.

Melihat rata-rata empirik yang dihasilkan oleh keseluruhan subjek yaitu sebesar 25,45 maka dapat diketahui bahwa penyesuaian diri anak berada dalam kategori masih berkembang. Demikian juga untuk variabel Self Esteem dengan rata-rata skor empirik 20,35 dengan kategori masih berkembang.

Untuk mengetahui pengaruh Self Esteem terhadap penyesuaian diri anak dilakukan uji t. Berdasarkan hasil analisis data menghasilkan nilai thitung $=5,078$ sedangkan ttabel $=1,989$. Karena thitung $(5,078)>$ ttabel $(1,989)$ dan $p$ pada taraf signifikansi $5 \%=2,021(p>0,05)$. Nilai p 2,021 menunjukkan hubungan tersebut signifikan. Artinya ada pengaruh yang signifikan antara Self Esteem terhadap penyesuaian diri. Sehingga dapat diinterprestasikan bahwa semakin tinggi tingkat Self Esteem, maka semakin tinggi penyesuaian diri anak. Hasil penelitian juga menunjukkan terdapat nilai koefisien R square (R2) sebesar 0,241 menunjukkan ada pengaruh Self Esteemterhadap penyesuaian diri anak.

Hal ini sesuai dengan hasil penelitian yang dilakukan sebelumnya oleh Listyaningsih yang menyimpulkan bahwa ada pengaruh yang signifikan antara penyesuaian diri terhadap perilaku sosial. Sehingga dapat diinterprestasikan bahwa semakin tinggi tingkat penyesuaian diri siswa cerdas istimewa dalam kelas akselerasi, maka semakin tinggi pula tingkat perilaku sosial yang ditunjukkan oleh siswa cerdas istimewa tersebut (Listyaningsih 2017)

Sesuai dengan penelitian yang dilakukan oleh (Putri \& Nurdin, 2017) yang menyimpulkan bahwa terdapat hubungan yang positif dan signifikan antara kepercayaan diri dengan penyesuaian diri anak usia 5-6 tahun di TK Negeri Pembina 2 Kota Pekanbaru. Berdasarkan hasil uji hipotesis yang diperoleh terdapat hubungan yang positif dan signifikan antara kepercayaan diri dengan penyesuian diri anak usia 5-6 tahun di TK Negeri Pembina 2 Kota Pekanbaru. Tingkat hubungan antara kepercayaan diri dengan penyesuaian diri termasuk dalam kategori sedang dengan nilai koefisien determinan sebesar $29 \%$, memiliki makna bahwa kepercayaan diri memberi pengaruh terhadap penyesuaian diri.

Penelitian yang dilakukan oleh (Nora 2015) tentang "Pengaruh Kelekatan diri dan Kemampuan Bersosialisasi Anak" menyimpulkan bahwa: (1) Terdapat pengaruh langsung positif kelekatan terhadap kemampuan bersosialisasi, (2) terdapat pengaruh langsung positif terdapat pengaruh langsung positif harga diri terhadap kemampuan bersosialisasi,dan (3) terdapat pengaruh langsung positif kelekatan terhadap harga diri.

Penyebaran distribusi frekuensi Self Esteem anak pada skor 13-15 diperoleh 6 orang anak dengan persentase 7,2\%, pada skor 16 -18 diperoleh 20 orang anak dengan persentase $24,1 \%$, pada skor $19-21$ diperoleh 23 orang anak dengan persentase $27,7 \%$, pada skor $22-24$ diperoleh 22 orang anak dengan persentase $26,5 \%$, pada skor 25-27 diperoleh 8 orang anak dengan persentase 9,6\%, pada skor 28-30 diperoleh 4 orang anak dengan persentese $4,8 \%$, pada skor $31-33$ di peroleh 0 orang anak dengan persentase $0 \%$. Berdasarkan data di atas, diketahui persentase terbesar adalah pada rentang skor 19-21 dengan persentase 27,7\%. Sejalan dengan penelitian (Ezdha and Sari 2019)) yang menyimpulkan bahwa ada hubungan yang erat antara pola asuh orang tua dengan Self Esteem anak usia prasekolah, dimana jika orang tua menerapkan pola asuh yang demokratis maka anak tersebut memiliki Self Esteem yang tinggi. 
Pada hasil uji korelasi diperoleh angka probabilitas sebesar 0,000. Dimana 0,000 lebih kecil dari 0,05 (0,000 $<0,05)$. Maka Ho ditolak artinya terdapat hubungan yang signifikan antara Self Esteem dengan Penyesuaian Diri. Koefisien korelasi yang dihasilkan adalah sebesar 0,491 yang terletak pada rentang 0,40-0,599 dengan kategori sedang (tabel 3.3) artinya hubungan antara Self Esteem dengan Penyesuaian Diri anak masuk dalam kategori sedang.

Data empirik koefisien determinasi yang dihasilkan adalah sebesar $r 2=0,241$. Artinya $24,1 \%$ variabel Self Esteem menentukan penyesuaian diri anak. Sedangkan arah hubungan adalah positif karena nilai $r$ positif. Berarti semakin tinggi SelfEsteem maka semakin tinggi pula penyesuaian diri anak Sejalan dengan penelitian Deltina Marta (2019) bahwa terdapat korelasi signifikan yang rendah self concept anak dengan penyesuaian diri pada anak panti asuhan Harapan Putra di Kelurahan Tangkerang Utara Kecamatan Bukit Raya Kota Pekanbaru. Artinyajika semakin tinggi self concept anak maka penyesuaian diri pada anak akan semakin rendah.

Untuk membuktikan pengaruh signifikan hubungan Self Esteem dengan penyesuaian diri anak dapat dilakukan uji f. Nilai ftabel dengan $\mathrm{dk}=\mathrm{n}-2=83-2=81$ pada taraf signifikan $5 \%$ sebesar 2,021. Dengan demikian diketahui fhitung $(25,785)>$ ftabel $(3,956)$ atau signifikan $(0,000)<5 \%(0,05)$. Dengan demikian dapat diartikan bahwa Self Esteem berhubungan signifikan dengan penyesuaian diri anak.

Tingkat hubungan antara dua variabel dilakukan dengan melihat angka koefisien korelasi yang mengacu kepada tabel interpretasi koefisien korelasi (Soegiyono, 2015). Untuk membuktikan pengaruh signifikan hubungan Self Esteem dengan penyesuaian diri anak dapat dilakukan uji f. Nilai ftabel dengan dk $=n-2=83-2=81$ pada taraf signifikan $5 \%$ sebesar 2,021. Dengan demikian diketahui fhitung $(25,785)>$ ftabel $(3,956)$ atau signifikan $(0,000)<$ $5 \%(0,05)$. Dengan demikian dapat diartikan bahwa Self Esteem berhubungan signifikan dengan penyesuaian diri anak.

\section{SIMPULAN}

Berdasarkan hasilm penelitian yang telah dilakukan, terdapat hubungan yang signifikan antara Self Esteem dengan penyesuaian diri anak usia 4-5 tahun di TK Negeri Pembina 2 Bengkalis Kecamatan Bengkalis Kabupaten Bengkalis. Hal ini berarti bahwa Self Esteem berpengaruh terhadap penyesuaian diri anak. Di mana anak dapat menyesuaikan diri dengan baik, anak dapat memilih dan melaksanakan pilihannya dan bertanggung jawab atas tindakannya, dan keadaan tersebut tidak mungkin tercapai tanpa adanya perilaku Self Esteem.

\section{DAFTAR PUSTAKA}

Aliyah, Siti, Ria Novianti, and Rita Kurnia. 2018. "The Relation of Assertive Behavior with Self- Adjusment of Children Aged 4-5 Years in PAUD Harapan Bunda Air Panas Village District of Pendalian IV Koto R Rokan Hulu Regency." JOM FKIP-UR 5:1-15.

Auni. Ulfa Nila 2017. "Hubungan Peran Ayah Dengan Penyesuaian Diri Pada Anak Usia 4-6 Tahun di Desa Gelang, Kecamatan Rakit, Kabupaten Banjarnegara."

Deltina, Marta, Ria Novianti, and Rita Kurnia. 2019. "Hubungan Self Concept Dengan Penyesuaian Diri Pada Anak Panti Asuhan Harapan Putra Di Kelurahan Tangkerang Utara Kecamatan Bukit Raya Kota Pekanbaru Marta." Jurnal Pendidikan Tambusai 3(6):1471-78.

Dwi, Hastuti. 2016. "Strategi Pengembangan Harga Diri Anak Usia Dini." JURNAL JPSD (Jurnal Pendidikan Sekolah Dasar) 2(2):38.

Ezdha, Awaliyah Ulfah Ayudytha, and Widya Artika Sari. 2019. "Hubungan Antara Pola Asuh Orang Tua Dengan Self Esteem Anak Usia Prasekolah Di TK Negeri Pembina LII Pekanbaru." Jurnal Ilmu Keperawatan (Journal of Nursing Sciences) 8:42-51.

Fatimah, Enung. 2010. Psikologi Perkembangan (Perkembangan Peserta Didik). Bandung: Pustaka Setia.

Fauziddin, M., \& Mufarizuddin, M. (2018). Useful of Clap Hand Games for Optimalize Cogtivite Aspects in Early Childhood Education. Jurnal Obsesi: Jurnal Pendidikan Anak Usia Dini, 2(2), 162. https://doi.org/10.31004/obsesi.v2i2.76.

Ghufron, Nur \&. Rini Risnawita. 2018. Teori-Teori Psikologi. Vol. 7. Jogjakarta: Ar-Ruzz Media.

Gunarsa, Singgih D. 2008. Psikologi Perkembangan Anak dan Remaja. Jakarta: Gunung Mulia.

Handono, O., and K. Bashori. 2013. "Hubungan Antara Penyesuaian Diri Dan Dukungan Sosial Terhadap Stres Lingkungan Pada Santri Baru." EMPATHY Jurnal Fakultas Psikologi 1(2):79-89.

Izzaty, Rita Eka, Dkk. 2017. Model Konseling Anak Usia Dini. Vol. 1.

Kemdikbud. 2015. Petunjuk Teknis Penyelenggaraan PAUD Holistik Integratif di Satuan PAUD.

Khasanah, Nurul Islamiyah Nur, Hadiyah Hadiyah, and Nurul Kusuma Dewi. 2019. "Hubungan Tingkat Harga Diri Terhadap Kecenderungan Perilaku Agresif Anak Usia 5-6 Tahun." Kumara Cendekia 7(3):227.

Listyaningsih, Astika. 2017. "Pengaruh Penyesuaian Diri Terhadap Perilaku Sosial Siswa Akselerasi Di SMP Negeri 3 Kediri." Kajian Moral Dan Kewarganegaraan. 05(1):522-36.

Mardhatillah, Nadia. 2017. "Strategi Layanan Bimbingan Dan Konseling Untuk Meningkatkan Self Esteem." Prosiding Seminar Nasional 140-48. 
Maria, Ilga, and Ria Novianti. 2017. "Pengaruh Pola Asuh Dan Bullying Terhadap Harga Diri Pada Anak Kelompok B TK Di Kota Pekanbaru." Jurnal Prodi Keguruan Universitas Riau 6(1):61-69.

Mruk, Christopher J. 1995. Self-Esteem: Research, Theory, and Practice.

Nora, Maya Oktia. 2015. "Pengaruh Kelekatan Dan Harga Diri Terhadap Kemampuan Bersosialisasi Anak." Pendidikan Usia Dini 9(2):379-338.

Putri, Rizki, and Zulkifli Nurdin. 2017. "Self Esteem The Correlation between Self Confidence and Self Adjusment Children Age 5-6 Years in Kindergartens Negeri Pembina 2 City of Pekanbaru." 1-13.

R. Raco. 2010. Metode Penelitian Kualitatif: Jenis, Karakteristik Dan Keunggulannya. Pertama. edited by C. R. Semiawan. Jakarta: Gramedia Widiasarana Indonesia.

Rahma, Aulia. 2016. "Hubungan Antara Penyesuaian Diri Dengan Kemandirian Belajar Siswa Kelas X SMA Excellent Al-Yasini Yang Tinggal Di Pondok Pesantren." 8(3):6-10.

Santrock, John W. 2012. "Life-Span Development, Edisi Ketigabelas." Jakarta: Erlangga.

Saputri, Herliana Rahmi. 2016. "Hubungan Antara Fashion Involvement \& Impulsive Buying dengan Harga Diri (Self Esteem) Pada Remaja Di SMAN 2 Samarinda." EJurnal Psikologi 4(3):249-59.

SISDIKNAS. 2003. "Undang Undang Sistem Pendidikan Nasional No. 20 Tahun 2003." Futures.

Sugiyono. 2012. Statistik Untuk Penelitian. Bandung: Alfabeta.

Sugiyono. 2015. Statistik Nonparametris Untuk Penelitian. Bandung: Alfabeta.

Sugiyono. 2018. "Metode Penelitian Kuantitatif , Kualitatif dan R\&D." Bandung: Alfabeta..

Suharsimi, Arikunto. 2013. "Prosedur Penelitian : Suatu Pendekatan Praktik (Edisi Revisi)."Jakarta:Rineka Cipta.

Susanti, A., and E. Widuri. 2013. "Penyesuaian Diri Pada Anak Taman Kanak-Kanak." EMPATHY Jurnal Fakultas Psikologi 1(1):16-30.

Susanto, Ahmad. 2015. Bimbingan Dan Konseling Di Taman Kanak-Kanak. Vol. 17. Jakarta: Prenadamedia Group.

Suwita, Pipit. 2016. "Tingkat Penyesuaian Diri Anak Yang Tinggal di Panti Asuhan (Studi pada Panti Asuhan Baiturrahmah Desa Rimbo Panjang Km.17 Kecamatan Tambang Kabupaten Kampar).” Jom Fisip 3(2):1-14.

Verdianingsih, Eliza. 2017. “Self-Esteem Dalam Pembelajaran Matematika." Eduscope 03(02):8-15. 